\title{
Skilled Worker
}

National Cancer Institute

\section{Source}

National Cancer Institute. Skilled Worker. NCI Thesaurus. Code C75554.

A worker who has acquired special skills. 